\title{
MIR27B Gene
}

National Cancer Institute

\section{Source}

National Cancer Institute. MIR27B Gene. NCI Thesaurus. Code C155665.

This gene may be involved in the negative regulation of CYP1B1 gene expression. 